\title{
The target group of the Ultimate Commission (Matthew 28:19)
}

Authors:

Kukzin Lee ${ }^{1}$

Francois P. Viljoen ${ }^{1}$

\section{Affiliations:}

${ }^{1}$ School of Biblical Studies and Bible Languages,

North-West University,

Potchefstroom campus,

South Africa

\section{Correspondence to:}

Francois P. Viljoen

email:

viljoen.francois@nwu.ac.za

\section{Postal address:}

School of Biblical Studies and Bible Languages,

North-West University

Private Bag X6001,

Potchefstroom 2520,

South Africa

\section{Keywords:}

Ultimate Commission:

Matthew 28:19; Jews;

Gentiles; discipleship

Dates:

Received: 28 Apr. 2009

Accepted: 09 July 2009

Published: 05 Mar. 2010

How to cite this article:

Lee, K. \& Viljoen, F.P.,

2010 , 'The target group of

the Ultimate Commission

(Matthew 28:19)',

HTS Teologiese Studies/

Theological Studies 66(1),

Art. \#184, 5 pages. DOI:

10.4102/hts.v66i1.184

This article is available at:

http:/ / www.hts.org.za

(c) 2010. The Authors.

Licensee: OpenJournals

Publishing. This work

is licensed under the

Creative Commons

Attribution License.

\section{ABSTRACT}

The inclusion of 'all nations' as the mission target in the Ultimate Commission of Matthew 28:19 somehow comes as a surprise. The Gentiles seem to have been excluded from Jesus' and his disciples' mission in two passages (10:5-6; 15:24). In an attempt to establish the target group of the great commandment, this article investigates the meaning of the phrase pant a t a;eghn as used in 28:19 and subsequently the literary contexts of the commandment.

\section{INTRODUCTION}

It is frequently acknowledged ${ }^{1}$ that the Ultimate Commission ${ }^{2}$ is important in understanding the whole gospel of Matthew. To Ellis (1974:22), the Ultimate Commission is Matthew's 'table of contents' located at the end. To Kupp (1996:201, italics his), it is 'the "abstract" for Matthew's "dissertation"' and 'a digest and telos of the work'. Byrne (2002:57-58) suggests that the beginning and the ending are more significant than others in our issue.

Whatever the Ultimate Commission's genre might be, ${ }^{3}$ it is closely linked with the overall scheme of the gospel. Readers of Matthew, if they have read Matthew from the beginning to the end with an open mind, will not be surprised at their encounter with the Ultimate Commission, even if they read it for the first time. Its themes are not sudden, but are already visible in every section of the gospel. While reading the gospel, readers would have been well prepared for the Ultimate Commission. So Brooks (1981:2) could say that 'the author was motivated to produce the work in keeping with' the Ultimate Commission. It is generally agreed that Matthew has reworked the Ultimate Commission in a redactioncritical sense (Meier 1977b:407-424), whether it is a thorough working (Bornkamm 1969:15; Brown 1980:193-21; Bultmann 1968:289) or a light touch (Beasley-Murray 1962:77-92). Michel (1995:44; cf. Barth 1963:133) also insists that three parts of the Ultimate Commission were originally independent and were put together by Matthew. In that case it is easy to see that the ending corresponds to the whole gospel.

The only possible surprise is the inclusion of 'all nations' as the mission target, because at least at the surface level, the Gentiles seem to have been excluded from Jesus' and his disciples' mission in two passages $(10: 5-6 ; 15: 24)$. The inclusion of the Gentiles in Jesus' ministry is, however, not totally new, but already visible in the whole of the gospel (Bauer 1998:121-124; Lee 1999:28-93; Viljoen 2007:259). Scholars have noticed the co-existence of universalism and particularism (Guthrie 1990:29-30). Readers too would have been prepared regarding this matter (Hubbard 1974:86). For example, we may include universalistic motives in Jesus' birth story, Jesus' prophecy about the worldwide proclamation of the gospel (24:14) and the inclusion of Gentiles in the kingdom of heaven (8:11), Jesus' ministry in the Gentile territory and healing of some Gentiles (8:5-13, 28-34; 15:21-28), Jesus' commending of the Gentiles for their good faith $(8: 10 ; 15: 28)$, and Jesus' parables showing universalistic tones: the parable of the mustard seed (13:31-32), the parable of the sower (13:38), the parable of vineyard workers (20:1-16), the parable of two sons (21:28-32), the parable of tenants (esp. 21:43), and the parable of the marriage feast (22:9-10). Matthew himself interprets Jesus' residence at Capernaum as meaningful to the Gentiles (4:14-16).

The focus of this article is to establish the target group in Jesus' commandment to make disciples. Scholars are divided on translating p a nt a $\mathrm{t} a$; e finh. Some scholars ${ }^{4}$ translate the phrase as 'all nations' or 'all peoples' and do not exclude Jews from the target. For them, Matthew's community could be either intra muros or extra muros. Others ${ }^{5}$ opt for 'all the Gentiles' as the translation of this phrase, thereby excluding Jews from the missionary target group. ${ }^{6}$ For them, Jews are now excluded from the mission of Matthew's community, whose tie with the synagogues has been totally or significantly broken, and whose social status is therefore extra muros.

1.cf. Bauer 1988:115-127; Blair 1960:45-47; Bornkamm 1971:205; Brooks 1981:2; Donaldson 1985:170, 188-190; Ellis 1974:22-25; Krentz 2006:23-41; Lohmeyer 1956:416; Luz 2000:66; Meier 1977b:407-424; Michel 1995:39-51; Trilling 1964:21; Vögtle 1964:266294.

2.Usually this is called 'the Great Commission', which implies its importance. Here we will use the term 'the Ultimate Commission' to convey the idea that it functions as a driving force in Matthew. cf. Arias (1991:410).

3.Various opinions in regard to literary genre or form (Gattung) have been suggested: a myth (Dibelius 1959:282-285), a cult legend Various opinions in regard to literary genre or form (Gattung) have been suggested: a myth (Dibelius 1959:282-285), a cult legend (Bultmann 1968:286), an enthronement hymn (Jeremias 1958:38-39; Michel 1995:36-37; for its critique cf. Bauer 1988:111-112, Friedrich 1983:137-183), a covenant formula (Frankemölle 1974:43-61), a combination of the royal decrees and the Old Testament
prophetic proof pattern (Malina 1970:88-91) and a commission (Hubbard 1974:62-72; also Stuhlmacher 2000:25; for its critique cf. prophetic proof pattern (Malina 1970:88-91) and a com
Hagner 1995:883; Gnilka 1988:502; Bauer 1988:113).

4.cf. Blomberg 1992:431-432; Carter 2000:552; Davies \& Allison 1997:684; De Kruijf 1993:19-29; France 1989:235-237; Gnilka 1988:508-509; Gundry 1994:595-596; Hagner 1995:887; Hahn 1965:125; Hill 1972:71-72; Keener 1997:401; Kvalbein 2000:54-57; Luz 2000:64; Meier 1977a:94-102; Nolland 2005:1265-1266; Saldarini 1994:59-60, 78-81; Segal 1991:24; Sim 1998:243; Stanton 1992:137-138; Trilling 1964:12-14, 26-28.

5.Such as Bavinck 1960:118; Clark 1980:1-8; Gager 1983:147; Gaston 1975:37-38; Hare 1967:148, 1979:39-40; Hare and Harrington 1975:359-369; Levine 1988:186-192; Luz 1995:139-140; Sparks 2006:655.

6. There are some scholars who try to understand the phrase denoting the diaspora Jews. Robinson, for example, suggests understanding the phrase as designating 'Jews of the Dispersion, those scattered among Gentile nations' (O'Brien 1976:73). Similarly Overman (1996:406) tries to understand the phrase as 'all the world'. 
In an attempt to establish the target group of the great commandment, we will at first investigate the meaning of the phrase pa at a $t a$; egnh as used in 28:19 by means of studies of the use of these words in the first gospel and the New Testament in general. Subsequently, the literary contexts of the commandment will be investigated.

\section{THE MEANING OF pa at a $t$ a ; equnh}

According to Bertram (1964:365), the Greek word" $€ \nu \eta$ is generally used in the LXX to render for the Hebrew גוים (the Gentiles), while $\lambda \alpha$ ó ${ }^{\prime}$ is used for עם (the chosen people). In the New Testament, however, both terms are sometimes used interchangeably, while in many passages we see the same phenomenon as in the LXX (Bertram \& Schmidt 1964:369-370). In Matthew, the meaning of the Greek word " $\epsilon \nu \circ \varsigma$ seems to differ according to whether it is singular or plural and whether it is modified by the adjective $\pi \hat{\alpha} \varsigma$. We can find 15 instances where Matthew uses the term: three times in the singular $(21: 43 ; 24: 7[2 x])$, four times in the plural with an adjective $\pi \hat{\alpha} \varsigma(24: 9,14 ; 25: 32 ; 28: 19)$ and eight times in the plural without an adjective $\pi \hat{\alpha} \varsigma(4: 15 ; 6: 32 ; 10: 5,18 ; 12: 18,21$ 20:19, 25).

\section{Gentiles: Used in the plural without $\pi \hat{\alpha} \varsigma$}

When the term is used in the plural without the adjective $\pi \hat{\alpha} c$, it seems to always mean 'Gentiles'. It seems that there is no difference in meaning whether it has an article or not.

Matthew 4:15 is the citation of Isaiah 9:1 [8:23 MT] and evidently defines the Galilean region as 'of the Gentiles' (Hagner 1993:74 Hare \& Harrington 1975:362; Meier 1977a:95; Sim 1998:220). By citing a passage from Isaiah, Matthew tells us that Zebulun and Naphtali are regions where there are many, or at least some, Gentiles.

In $6: 32$, the term is used pejoratively to denote a group of people who are interested only in worldly things. Based on our understanding that in the Second Temple period the Gentiles were generally despised in this way, and on our assumption that Jesus' audience were Jews, the most probable meaning of the term is 'the Gentiles' (Hare \& Harrington 1975:362; Meier 1977a:95). Matthew 6:32 shows that the word " $€ \nu \eta$ can be used interchangeably with its cognate word ' $\epsilon \nu \nu$ เкós, which always renders a derogatory meaning in Matthew $(5: 47 ; 6: 7 ; 18: 17)$.

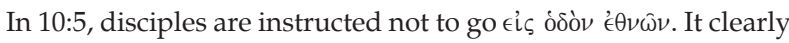
refers to the Gentiles, because it is coupled with Samaritans to be compared to the lost sheep of Israel.

In 10:18 it is prophesied that the preachers will be dragged before governors and kings to bear witness before them and toi $\varsigma$ " $\theta \nu \in \sigma\llcorner\nu$. Since they seem to be distinguished from those who flog

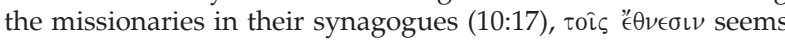
to denote the Gentiles.

We have two instances in 12:18-21 where Isaiah 42:1-4 is cited. Matthew uses the word " $\epsilon v \eta$ as a translation of two Hebrew words, גויים Matthew probably has not translated (or targumised) the quotation independently (pace Stendahl 1968:109), but might have utilised the already existing version available to him (Menken 2005:54, 67-88). We have no specific reason to think that Matthew is changing the original sense of the Hebrew words here by introducing the Greek word (pace Nolland 2005:493).

In 20:19, Jesus prophesied that the Son of Man would be

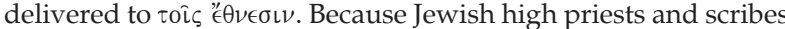

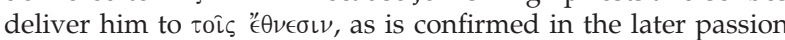
narrative, it obviously refers to the Gentiles.

In 20:25, Jesus holds the rulers of the ' $\epsilon \theta \nu \hat{\omega} \nu$ as a contra-model for his disciples not to imitate. Even though every ruler, either Jewish or Gentile, has a tendency to exercise authority over the people, and even though it is more natural to think that the comparison is made not to the Jewish rulers but to the disciples, it is better to translate the word as 'Gentiles' (see Hare \& Harrington 1975:362; pace Meier 1977a:96). By adding $\tau \hat{\omega} \nu \epsilon^{\epsilon} \theta \nu \hat{\omega} \nu$ to the rulers, Jesus seems to be emphasising the derogatory meaning (cf. 6:32; also see 5:47; 6:7; 18:17). However, it is also possible in 20:25 to translate the word as 'nations'.

\section{A nation: Used in the singular}

When the term is used in the singular, it seems to mean 'a people' in a collective sense or 'a nation' in a political sense, depending upon its context.

In $21: 43$, it is said that the vineyard will be given to " $\epsilon$ $\theta \nu \mathrm{L}$ who produces its fruits. Here obviously it cannot be a nation as a political unit, but a people in a collective sense (Meier 1977a:97) Here we see a contrast between Israel and the church, a new people, which is 'composed indiscriminately of Jews and Gentiles' (Hare \& Harrington 1975:363). ${ }^{7}$ Therefore, the term includes Jews. ${ }^{8}$

We have two instances of the term in 24:7. Here Meier (1977a:98) argues that one " $\epsilon \nu 0 \varsigma$ refers to the Jewish people while the other refers to some other nation engaging them in war, based on the idea that this could allude to the Jewish revolt in 66-70 CE (see also Hare \& Harrington 1975:362). Thus the possibility exists that " $\theta^{\prime} \nu \circ \varsigma$ denotes the Jewish people. However, the text does not necessarily depict a situation of 'Israel' and Israel's engagement in war with another nation is not mentioned in the text. ${ }^{9}$ Matthew 24:7 rather explains 24:6, 'You will hear of wars and rumours of wars'. Matthew 24:7 tells of future wars between the nations. Here Israel could probably be the nation who will be engaged in these wars. But the first and primary reference of the term in this case is 'a nation'.

\section{All nations: Plural with $\pi \hat{\alpha} \varsigma$}

When the term is used in the plural with an adjective $\pi \hat{\alpha} \varsigma$, it seems to always mean 'all nations', not necessarily excluding Israel. We have four such cases in Matthew.

In 24:9, we hear an apocalyptic warning from Jesus that the disciples will be hated by $\pi \dot{\alpha} \nu \tau \omega \nu \tau \hat{\omega} \nu \dot{\epsilon}^{\prime} \theta \nu \hat{\omega} \nu$ because of his name. Here it seems that 'all nations' fits better in this context, because the text refers to the severity of the tribulation. It is also said in 10:17 that the disciples are to be persecuted by the Jews. Both 10:17 and 24:9, probably both dependent on Mark 13:9-13, could refer to the same situation (Meier 1977a:97; Trilling 1964:27). Hare and Harrington (1975:362) appeal to the alteration Matthew has made to Mark 13:13, which shows the evangelist's intention to change the impact. However, the author's intention is not as clear as they think. Matthew simply would have understood it as Mark did. We have no reason to exclude Israel from the view. In 24:14, we have an apocalyptic prophecy of Jesus about the end. Here it is said that before the end the gospel of the kingdom will be proclaimed throughout the whole world as a testimony to

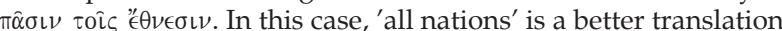

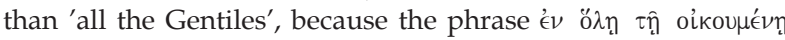
conveys the idea that there will be no people or nation 'left behind' in hearing the gospel (Zahn 1903:655).

In 25:32, we are informed about the last judgement in heaven. There $\pi \dot{\alpha} \nu \tau \alpha$ $\tau \dot{\alpha}{ }^{\prime \prime} \theta \nu \eta$ will be summoned before the heavenly Judge. Even though it is unclear what 'the least of my brethren' refers to (for various opinions see Davies \& Allison 1997:422), it is natural to assume that it is a final judgement and here every nation including the Jews will be summoned (Trilling 1964:27).

7.Ironically, Hare and Harrington categorise 21:43 in the passages that obviously mean Gentiles, while acknowledging the inclusion of the Jews on the same page.

8.cf. Buchanan $(1996: 838,841)$ thinks the term does not denote the Gentiles, but the Jewish nation only, while taking the wicked tenants as Romans who 'instead of adequately financing Palostine by paing "ren", in fact, collected taxes from thei adequately financing Palestine by paying 'rent, in fact, collected taxes from their heirs, the rightful owners of the vineyard. As creative as this may be, it cannot
explain the response of the chief priests and the Pharisees (v.45).

9.This is an example of scholarly attempts to historicise the text. Historical understanding should serve to clarify a text, not impose a meaning upon it. 
Hare and Harrison (1975:364-365; see also Hooker 1971:363), however, presuppose two judgements and insist that this is a judgement for the non-Christian Gentiles. The Matthean context, however, does not support the two judgements and there is no reason to exclude the Jews (Davies \& Allison 1997:422-423).

\section{Usage in the rest of the New Testament}

So far we have come to the following observation with regard to Matthew's use of the word: the plural form without the adjective $\pi \hat{\alpha} \zeta$ usually denotes 'Gentiles', while the plural form with the adjective $\pi \hat{\alpha} \varsigma$ is used to denote 'all nations' (Nolland 2005:1266; pace Luz 2005:249). We will now examine whether our observation in Matthew is also applicable to the rest of the New Testament. Our word " $\Leftrightarrow$ vos is used 147 times in the rest of the New Testament, among which 19 cases are used with the adjective $\pi \hat{\alpha} \varsigma .{ }^{10}$ Among them, 17 cases are used to primarily denote the meaning 'all nations' (Luke 24:47; Acts 2:5; 10:35; 14:16; 17:26; Romans 1:5; 15;11; 16:26; Galatians 3:8; 2 Timothy 4:17; Revelation 7:9; 12:5; 14:6, 8; 15:04; 18:03; 18:23), which does not exclude Jews or Israel in their concept, except Acts 2:5. Even in Acts 2:5, the phrase is used to denote the idea that there were people from every corner of the world. It is used as an opposite concept to ' $a$ ' nation, not to 'Israel'. There are two cases in which the primary meaning should be 'all the Gentiles' (Luke 21:24; Acts 15:17). From our observation, we have found that the phrase can be used either to denote 'all nations' or 'all the Gentiles', while the former usage is more common in the New Testament in its entirety. ${ }^{11}$

We have come to the conclusion that the target of the mission charge of the Ultimate Commission is 'all nations'. There was no other choice for Matthew but $\pi \dot{\alpha} \nu \tau \alpha$ $\tau \grave{\alpha}{ }^{\prime \prime} \theta \nu \eta$ in order to convey the idea that the commission was aimed at all human

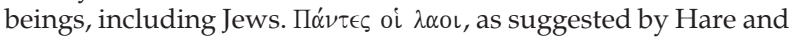
Harrington (1975:368), cannot work for Matthew, because the word $\lambda \dot{\alpha} 0 \varsigma$ usually means the people of Israel only $(1: 21 ; 2: 4,6$; $\left.4: 16,^{12} 23 ; 13: 15 ; 15: 8 ; 21: 23 ; 26: 3,5,47 ; 27: 1,25,64\right)$. Translating the phrase as 'all the Gentiles' and thereby excluding the Jews from its connotation does not coincide with the risen Lord's claim of the universal authority (Kvalbein 2000:54-55; Stuhlmacher 2000:27). The word study favours the translation of the phrase as 'all nations' rather than 'all the Gentiles'.

However, a word study cannot deductively define the usage of a word or phrase in any specific sentence. Therefore, we need to look at its immediate literary context (Levine 1988:187-188; Silva 1983:137-148).

\section{THE ULTIMATE COMMISSION IN ITS LITERARY CONTEXT}

Even though we have come to the conclusion through the word study in the previous section that the phrase $\pi \dot{\alpha} \nu \tau \alpha \tau \dot{\alpha}^{\prime \prime}{ }^{\prime \prime} \theta \nu \eta$ should be rendered as 'all nations' rather than 'all the Gentiles', it is necessary to examine the Ultimate Commission in its literary context.

Those who see the Ultimate Commission from a literary point of view tend to regard the Ultimate Commission as exclusive of Jews. They often include the following in their reasoning. Firstly, in the resurrection narrative the Jews are described as rejecting Jesus. Luz (2005:249), for example, suggests a comparison between the disbelief of 'Jews' in 28:15 and the mission to 'the Gentiles' in 28:19. Secondly, the Ultimate Commission is

10.In the case of Luke 12:30 the adjective may modify " $€ \theta \nu \eta$ o $\tau \alpha \hat{v} \tau \alpha$. If the former, the count will be 20 .

11.In the case of the $L X X$, we have quite a different result. Seeing as the word " $\epsilon$ $\theta \nu$ occurs 1010 times, let us narrow down our study to the Pentateuch, excluding Genesis, where Israel does not, as yet, exist as a nation. Among 115 occurrences of the word in Exodus through Deuteronomy, the plural form with the adjective $\pi \hat{\alpha} \nu$ fet 27 times. All of them Deuturive $\pi \alpha \nu$ 作 o be a result of the special relationship that existed between Israel and the othe . chosen or distinguished. Ultimate Commission.

12.Luz 2007:159; Sim 1998:220. compared and opposed to Jesus' earlier command (10:5-6). So the Ultimate Commission implies that 'for Matthew's church the orientation toward the mission of Israel has been replaced by the world-mission' (Luz 2005:249). Thirdly, Luz (2005:14) regards the story of the magi and other elements related to Jesus' nativity as 'the clearest signals' to the ending of the Jesus story. If the literary devices of Matthew point to transferring the special status from Israel to the Gentiles, the possibility of translating 28:19 as 'all the Gentiles' would become more of a probability. In order to evaluate their argument, we first need to establish the plot of Matthew.

\section{The plot of Matthew}

Matthew's story consists of 'the prologue and five main sections' (Luz 2005:244-245). The prologue not only covers the birth of Jesus, but also anticipates his whole story. According to Luz, the main narrative thread of the Gospel of Matthew 'tells... a story of Jesus' increasing conflict in Israel' (Luz 2005:246). Jesus' ministry has revealed 'Israel's unrepentant cities' (ibid.). Jesus and his disciples withdrew from Israel's leaders. Later 'Jesus confronts Israel and its leaders' (ibid.) and 'leaves Israel's temple'(ibid.). 'The Passion and Easter narratives...have a double ending. The story of Jesus' resurrection (28:1-10) is a story of death for Jews and its leaders. They fail to recognise "to this day" (28:15) the truth of Jesus' resurrection.'(ibid.). 'The two pericopes 28:11-15 and 16-20 mark the double ending of Matthew's story, leading to a hopeless situation for Jews and a new mission within salvation history for the community' (ibid.). This inclusive story implies the situation of Matthew's community. 'In future their mission to the Gentiles will be central. The mission to Israel is complete' (ibid.).

In his analysis of the immediate literary context, Luz (2005:246) insists that the parable of the wicked tenants implies that the kingdom of God will be taken not only from Israel's leaders but also from the people of Israel to be transferred to a new people (i.e. the Gentiles). In the next parable on the wedding banquet, Luz sees the Gentile mission after the destruction of the city. Luz (2005:247) also finds a shift of the announcement of judgement. It has been addressed initially only to the leaders (23:1-33), but later also to 'this generation (23:35-36). Now 'the whole people, led astray by their leaders, will be subjected to judgement'. Also the lament over Jerusalem (23:37-39) implies that the whole people was rejected. Luz (2005:250) insists that for Matthew 'the mission to Israel is over'.

Similarly to Luz, Matera (1987:243) asserts that the plot of Matthew's Gospel concerns the rejection of Jesus' messiahship and the movement of the Gospel from Israel to the nations'. He takes notice of the following features in Matthew's plot. Firstly, even though Matthew organises his narrative according to the life of Jesus, the inclusion of his genealogy, 'which extends back to Abraham' (241), and of the resurrection appearance, which 'points to the close of the ages' (ibid.), implies that 'the plot of Matthew's gospel has something to do with salvation history' (ibid.). Secondly, 'the effective response Matthew's narrative seeks to produce' can be glimpsed in the Ultimate Commission (242). Matthew's plot makes use of causality, according to Matera (ibid.), to expect 'the readers to worship Jesus as the risen Lord and to be confident that he is present to the church until the close of the age' (ibid.). Thirdly, in terms of 'a sense of inevitability and necessity', Matera (242-243) analyses that the attitude of Israel toward Jesus has changed from initial acceptance to later rejection.

Most of Matera's analysis of the plot of Matthew is acceptable. However, his analysis of inevitability and necessity of the plot is disputable. Luz and Matera have emphasised 'Israel's role' too much in their rejection. Matthew's emphasis is not on 'Israel' but on 'rejection'. In Matthew, the Gentiles play roles in the rejection of Jesus, too $(10: 18 ; 10: 18-19 ; 27: 26,27-31,54) \cdot{ }^{13}$ Rejection of Jesus was a universal phenomenon, as much as reception of him was

13.The response of Gadarenes (8:28-34) to Jesus' miracle cannot be taken as the Gentiles' rejection of Jesus (pace Sim 1995:23), but rather as their awe of Jesus. 
also universal. Rejection was great, while reception was little. Interestingly, current Matthean scholarship is divided on who persecuted Matthew's community. Hare (1967), on the one hand, suggests Jewish persecution, while Sim (1998:231-236), on the other hand, suggests Gentile persecution. Matthew's inclusive story, however, reveals that there was universal persecution of Matthew's community.

So the inevitability and necessity of the plot of Matthew is not Israel's rejection of Jesus while the nations show interest. Rather it is 'Jesus' victory over the whole world' (Wright 1996). Universal rejection of Jesus was overcome by his resurrection from the dead and now his victory should be proclaimed universally.

The contrast between Jesus' first mission charge (10:5-6) and his last command (28:19) has been made often. These two mission charges make the contrast possible. The Ultimate Commission is usually taken either as 'a replacement' or 'an expansion' of Jesus' first mission charge (Levine 1988:191; Luz 2005:249). If it is regarded as a replacement the Ultimate Commission would exclude the Jews in its scope. However, if it is regarded as an expansion it would include the Jews.

The most immediate literary context of the command to make disciples is the risen Jesus' claim of authority over heaven and earth. The command to make disciples is closely related to the claim of authority through the use of the conjunction ouv ${ }^{14}$ It is, therefore, most natural to assume that the scope of the Ultimate Commission does include humanity as a whole and does not exclude the Jews (Carter 2000:552; Davies \& Allison 1997:684; Kvalbein 2000:54-55)

\section{An eschatological event?}

Sim (1995:43-44) is not of the opinion that the Gentile mission was the task taken by Matthew's community. He (1998:244) insists that Matthew's community might have approved the validity of the universal mission without actually being involved in it. He asserts that the risen Lord's command to make disciples of all nations is not binding for Matthew's community. Ironically he argues that the same command is the binding teaching for law observance, including the circumcision (Carter 2004:279 n.64). He pushes the Gentile mission to the

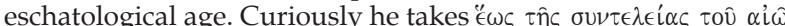
vos as conforming to his interpretation. So the universal mission becomes an eschatological event and not urgent for Matthew's community. They did not interpret the Ultimate Commission, according to Sim (1995:42), 'as a command to pursue a mission to the Gentile. Here Sim seems to be an omniscient novel writer, who can penetrate into the minds of the characters of his novel' (Foster 2004:242). Maybe Sim's assertion can be defeated by his own words. In order to criticise the idea that the conservative evangelist has kept the particularistic sayings although he does not agree with them, Sim (1995:30) writes: 'The mere fact that Matthew has incorporated them into his Gospel betrays his ready agreement with them'. Thus the incorporation of the Ultimate Commission in Matthew indicates that Matthew's community has already taken the commission as their mission. The risen Lord's promise to be with his disciples 'to the end of the age' (Mt 28:20) should not be taken as a basis for the delay of the Gentile mission. Rather his promise is issued for assurance (Carter 2000:553). Based upon his promise, disciples are to go boldly to make disciples of all nations. They should not hesitate in accomplishing their mission, because the Lord is helping them (Davies \& Allison 1997:687).

Acknowledging that the Ultimate Commission is not as straightforward as he thinks, Sim (1998:244) relies on 24:14 Foster (2004:243-244) wittily criticises Sim's attempt to build his case that the Gentile mission is an eschatological event upon 24:14: If this cannot be a good ground for the Gentile mission being supported in Matthew's community (Sim 1998:242-243),

14. Textual evidence strongly supports this, though there are other variants. Manuscripts like N, A, 0148 vid, f13, Maj, and bo ${ }^{\mathrm{pt}}$ omit oûv, while D has vvv instead. then it also cannot be a strong base for his case. Based on 24:14, Sim (1995:244) argues that according to the evangelist's timetable, the gospel will be preached throughout the whole world 'just prior to the end of the age'. To him, the passage has turned out to be about Matthew's community's inaction rather than their involvement in the Gentile mission. However, the passage should be interpreted as 'an incentive to Matthew's audience to start the mission in their present situation' (Foster 2004:244)

\section{CONCLUSION}

Based on this investigation it appears that the target group of the Ultimate Commission is 'all nations', which includes Jews, and not 'all the Gentiles', exclusive of Jews. Based on the word study of $\pi \alpha \dot{\alpha} \nu \tau \alpha \dot{\alpha}^{\prime}{ }^{\prime} \theta \nu \eta$ in the first gospel and the New Testament in general it is clear that Matthew conveys the idea that the commission was aimed at all human beings, including Jews. The examination of the Ultimate Commission in its literary context confirms that the scope of the Ultimate Commission does include humanity as a whole and does not exclude the Jews.

The evangelist expects his readers to take part in the universal mission. Jesus has been raised from the dead and claims universal authority. The same Jesus calls his disciples to go and make disciples of all nations. The readers will identify themselves with the disciples. Matthew's community has engaged in the universal mission.

\section{REFERENCES}

Arias, M., 1991, 'Church in the World: Rethinking the Great Commission', Theology Today 47, 410-418.

Barth, G., 1963, 'Matthew's understanding of the law', in G. Bornkamm, G. Barth \& H.J. Held (eds.), Tradition and interpretation in Matthew, pp. 58-164, SCM, London.

Bauer, D.R., 1988, The structure of Matthew's gospel: A study in literary design, Almond, Sheffield.

Bavinck, J.H., 1960, An introduction to the science of missions, Presbyterian \& Reformed, Philadelphia.

Beasley-Murray, G.R., 1962, Baptism in the New Testament, Eerdmans, Grand Rapids.

Bertram, G \& Schmidt, K.L., 1964, 'egno , ejpnikow', in G. Kittel (ed.), Theological dictionary of the New Testament, vol. 2, pp. 364-372, Eerdmans, Grand Rapids.

Blair, E.P., 1960, Jesus in the gospel of Matthew, Abingdon, New York.

Blomberg, C.L., 1992, Matthew, Broadman, Nashville.

Bornkamm, G., 1969, Early Christian experience, Harper \& Row, New York

Bornkamm, G., 1971, 'The risen Lord and the earthly Jesus, Matthew 28:16-20', in J.M. Robinson (ed.), The future of our religious past: Essays in honour of Rudolf Bultmann, pp. 203 229, SCM, London.

Brooks, O.S., 1981, 'Matthew xxviii 16-20 and the design of the first gospel', Journal for the Study of the New Testament 10, 2-18.

Brown, S., 1980, 'The Matthean community and the Gentile mission', Novum Testamentum 22, 193-221.

Buchanan, G.W., 1996, The gospel of Matthew, vol. 2, Mellen Biblical Press, Lewiston.

Bultmann, R., 1968, The history of the synoptic tradition, Harper \& Row, New York.

Byrne, B., 2002, 'The Messiah in whose Name "the Gentiles will hope" (Matt 12:21): Gentile inclusion as an essential element of Matthew's Christology', Australian Biblical Review 50, 55-73.

Carter, W., 2000, Matthew and the margins: A socio-political and religious reading, Sheffield Academic Press, Sheffield.

Carter, W., 2004, 'Matthew and the Gentiles: Individual conversion and/or systemic transformation?' Journal for the Study of the New Testament 26, 259-282.

Clark, K.W., 1980, The Gentile bias in Matthew and other essays, Brill, Leiden.

Davies, W.D. \& Allison, D.C., 1997, A critical and exegetical commentary on the gospel according to Saint Matthew, vol. 3 T\&T Clark, Edinburgh. 
De Kruijf, T.C., 1993, 'Go therefore and make disciples of all nations: Mt 28:19', Bijdragen 54, 19-29.

Dibelius, M., 1959, Die Formgeschichte des Evangeliums [The formal criticism of the Gospels], J.C.B. Mohr, Tübingen.

Donaldson, T.L., 1985, Jesus on the mountain: A study in Matthean theology, JSOT Press, Sheffield.

Ellis, P.F., 1974, Matthew: His mind and his message, Liturgical Press, Collegeville.

Foster, P., 2004, Community, law and mission in Matthew's gospel, Mohr Siebeck, Tübingen.

France, R.T., 1989, Matthew: Evangelist and teacher, Paternoster Press, Exeter.

Frankemölle, H., 1974, Jahwebund und Kirche Christi: Studien zur form- und traditionsgeschichte de 'Evangeliums' nach Matthäus [Yaweh covenant and the Church of Christ: Studies on form and tradition of the 'Gospel' according to Matthew], Aschendorff, Münster.

Friedrich, G., 1983, 'Die formale Struktur von Matt 28:18-20 [The formal structure of Matt 28:18-20]', Zeitschrift für Theologie und Kirche 80(2), 137-183.

Gager, J.G., 1983, The Origins of Anti-Semitism: Attitudes toward Judaism in Pagan and Christian antiquity, Oxford University Press, New York.

Gaston, L., 1975, 'The Messiah of Israel as teacher of the Gentiles: The setting of Matthew's Christology', Interpretation 29, $24-$ 40.

Gnilka, J., 1988, Das Matthäusevangelium [The Gospel of Matthew], vol. 2, Herder, Freiburg.

Gundry, R.H., 1994, Matthew: A commentary on his handbook for a mixed church under persecution, 2nd edn., Eerdmans, Grand Rapids.

Guthrie, D., 1990, New Testament introduction, 2nd edn., Apollos, Leicester.

Hagner, D.A., 1993, Matthew 1-13, Word Books, Dallas.

Hagner, D.A., 1995, Matthew 14-28, Word Books, Dallas.

Hahn, F., 1965, Mission in the New Testament, Allenson, Naperville.

Hare, D.R.A., 1967, The theme of Jewish persecution of Christians in the Gospel according to St. Matthew, Cambridge University Press, Cambridge.

Hare, D.R.A. \& Harrington, D.J., 1975, “"Make disciples of all the Gentiles" (Mt 28:19)', Catholic Biblical Quarterly 37, 359-369.

Hill, D., 1972, The gospel of Matthew, Oliphants, London.

Hooker, M.D., 1971, 'Uncomfortable words. X. The prohibition of foreign missions (Mt 10:5-6)', Expository Times 82, 361-365.

Hubbard, B.J., 1974, The Matthean redaction of a primitive apostolic commissioning: An exegesis of Matt. 28:16-20, Scholars Press, Atlanta.

Jeremias, J., 1958, Jesus' promise to the nations: The Franz Delitsch lectures for 1953, Allenson, Naperville.

Keener, C.S., 1997, Matthew, Intervarsity Press, Downers Grove.

Krentz, E., 2006, "'Make disciples" - Matthew on evangelism', Currents in Theology and Mission 33, 23-41.

Kupp, D.D., 1996, Matthew's Emmanuel: Divine presence and God's people in the first gospel, Cambridge University Press, Cambridge.

Kvalbein, H., 2000, 'Has Matthew abandoned the Jews?', in J. Ådna \& H. Kvalbein (eds.), The mission of the early church to Jews and Gentiles, pp. 45-62, Mohr Siebeck, Tübingen.

Lee, K., 1999, 'Jesus and the Gentiles in Matthew', ThM thesis, Gordon-Conwell Theological Seminary, South Hamilton.

Levine, A.-J., 1988, The social and ethnic dimensions of Matthean social history: 'Go nowhere among the Gentiles...' (Matt. 10:5b), Mellen Biblical Press, Lewiston.

Lohmeyer, E., 1956, Das Evangelium des Matthäus [The Gospel of Matthew], Vandenhoeck \& Ruprecht, Göttingen.
Luz, U., 1995, The theology of the gospel of Matthew, Cambridge University Press, Cambridge.

Luz, U., 2000, 'Has Matthew abandoned the Jews? A response to Hans Kvalbein and Peter Stuhlmacher concerning Matt 28:16-20', in J. Ådna \& H. Kvalbein (eds.), The mission of the early church to Jews and Gentiles, pp. 63-68, Mohr Siebeck, Tübingen.

Luz, U., 2005, Studies in Matthew, Eerdmans, Grand Rapids.

Luz, U., 2007, Matthew 1-7: A commentary, Fortress Press, Minneapolis.

Malina, B.J., 1970, 'The literary structure and form of Matt. xxviii 16-20', New Testament Studies 17, 87-103.

Matera, F.J., 1987, Passion narratives and gospel theologies: Interpreting the synoptics through their passion stories, Paulist, New York.

Meier, J.P., 1977a, 'Nations or Gentiles in Matthew 28:19?', Catholic Biblical Quarterly 39, 94-102.

Meier, J.P., 1977b, 'Two disputed questions in Matt 28:16-20', Journal of Biblical Literature 96, 407-424.

Menken, M.J.J., 2005, Matthew's Bible: The Old Testament text of the evangelist, Leuven University Press, Leuven.

Michel, O., 1995, 'The conclusion of Matthew's gospel: A contribution of the history of the Easter message', in G. Stanton (ed.), The interpretation of Matthew, 2nd edn., pp. 39-51, T\&T Clark, Edinburgh.

Nolland, J., 2005, The gospel of Matthew: A commentary on the Greek text, Eerdmans, Grand Rapids.

O'Brien, P., 1976, 'The Great Commission of Matthew 28:18-20. A missionary mandate or Not?', The Reformed Theological Review 35, 66-78.

Overman, J.A., 1996, Church and community in crisis: The gospel according to Matthew, Trinity Press, Valley Forge.

Saldarini, A.J., 1994, Matthew's Christian-Jewish community, University of Chicago Press, Chicago.

Segal, A.F., 1991, 'Matthew's Jewish voice', in D.L. Balch (ed.), Social history of the Matthean community: Cross-disciplinary approaches, pp. 3-37, Fortress Press, Minneapolis.

Silva, M., 1983, Biblical words and their meaning: An introduction to lexical semantics, Zondervan, Grand Rapids.

Sim, D.C., 1995, 'The gospel of Matthew and the Gentiles', Journal for the Study of the New Testament 51, 19-48.

Sim, D.C., 1998, The gospel of Matthew and Christian Judaism, T\&T Clark, Edinburgh.

Sparks, K., 2006, 'Gospel as conquest: Mosaic typology in Matthew 28:16-20', Catholic Biblical Quarterly 68, 651-663.

Stanton, G.N., 1992, A gospel for a new people: Studies in Matthew, John Knox, Louisville.

Stendahl, K., 1968, The school of Matthew and its use of the Old Testament, Fortress Press, Philadelphia.

Stuhlmacher, P., 2000, 'Matt 28:16-20 and the course of mission in the apostolic and postapostolic age', in J. Ådna \& H. Kvalbein (eds.), The mission of the early church to Jews and Gentiles, pp. 18-43, Mohr Siebeck, Tübingen.

Trilling, W., 1964, Das wahre Israel: Studien zur theologie des Matthäus-Evangeliums [The true Israel: Studies on the theology of the Gospel of Matthew], Kösel, München.

Viljoen, F.P., 2007, 'The Matthean community according to the beginning of his gospel', Acta Theologica 26(2) 242-262.

Vögtle, A., 1964, 'Das christologische und ekklesiologische Anliegen von Mt 28:18-20 [The Christological and ecclesiastical concerns of Matthew 28:18-20]', Studia Evangelica 2, 266-294.

Wright, N.T., 1996, Jesus and the victory of God, Fortress Press, Minneapolis.

Zahn, M., 1903, Das Evangelium des Matthaus [The Gospel of Matthew], Deichert, Leipzig. 